For the most up-to-date list of IDM events, please visit the IDM website at www.theidm.com

\section{January 2003}

\section{February 2003}

\section{March 2003}

\section{Diary}

\section{January}

\section{Monitoring Media Performance}

London

This event brings together industry experts to demonstrate media accountability across $T V$, radio, newspapers and magazines.

Tel: +44 (0)1491411000

Fax: +44 (0)1491 418600

E-mail: conferences@warc.com

Website: http://store.warc.com/ProductInfo/3262.asp.

\section{January}

Mobile Marketing and Advertising

London

Learn how to reach the customer using SMS, MMS and games.

Tel: +44 (0)1932893853

Fax: +44 (0) 1932893893

E-mail: cust.serv@informa.com

Website: www.ibcglobal.com/cod/search.asp?C $=\mathrm{T} \& \mathrm{CID}=\mathrm{UKC}$

23 January

IDM Members' Evening with Peter Mouncey

London

Contact: Jayne Swanson

Tel: + 44 (0)20 86140269

E-mail: jayneswanson@theidm.com

Website: www.theidm.com/events

29 January

Brand Summit 2003

London

This summit will bring together the directors of Europe's most powerful global brands to give their insight into how best to manage brands over the next decade.

Tel: +44 (0)20 79704770

Fax: $+44(0) 2079704799$

E-mail: conferences@centaur.co.uk

Website: www.centaur-conferences.co.uk.

\section{February}

Retail Summit

London

This summit is aimed at senior retail marketers and management who implement and manage customer-driven strategies. It will tackle retention from the initial stages of understanding customers to driving loyalty further and reaping the incremental benefits of costly marketing strategies.

Tel: +44 (0)20 79704770

Fax: +44 (0)20 79704799

E-mail: mwconferences@centaur.co.uk

Website: www.centaur.co.uk/public/conf/rs/overview.asp.

11 February

Direct Marketing Management Forum

London

An opportunity for marketing and direct marketing managers to review the current direct marketing agency scene and update themselves on database, CRM and direct marketing production services. The event includes a series of free senior-level workshops.

Tel: +44 (0)1920 444202

Fax: +44 (0)1920 465569

E-mail: info@forumevents.co.uk

Website: www.forumevents.co.uk.

2 March

International Direct Marketing Fair

London 
The International Direct Marketing Fair covers every facet of direct marketing, whether it is via the envelope or e-mail, the phone or the mobile, delivered by post or the Web.

Tel: +44 (0)20 82712123

Fax: +44 (0)20 83340725

Website: www.idmf.co.uk/

3 March

\section{CRM Summit}

London

For those just beginning a CRM initiative or evaluating an existing one, this event will provide an opportunity to learn how to identify key business and IT imperatives, align business goals with CRM, select the vendors, evaluate and select appropriate CRM technologies and architectures, integrate people, processes and technology solutions and build and maintain a robust CRM culture.

Tel: +1 2033166757

E-mail: ashley.pearce@gartner.com

Website: www.gartner.com/2_events/conferences/2003/crs3/crs3.jsp

4 March

\section{World Customer Contact Centre Exchange}

London

The challenge of the 2000s is for organisations to turn their call centres into multimedia contact centres. WCCC Exchange 2003 will focus on the next-generation contact centre, featuring all the key areas of concern for the contact centre director.

Tel: +44 (0)2073689300

Fax: +44 (0)2073689301

E-mail: exchange@iqpc.co.uk

Website: www.iqpc.co.uk. 